\title{
PERBANDINGAN SKOR DISMENOREA PADA PASIEN ENDOMETRIOSIS YANG MENDAPATKAN TERAPI ABLASI LAPAROSKOPI DILANJUTKAN GnRH AGONIST VERSUS ABLASI LAPAROSKOPI SAJA DI RSUP DR. SARDJITO YOGYAKARTA
}

\author{
Marta Isyana ${ }^{1}$, Djaswadi Dasuki ${ }^{2}$, Diah Rumekti ${ }^{3}$
}

\begin{abstract}
Background: Dysmenorrhea in endometriosis is a condition that adversely impacts the quality of life of women. The current treatment for dysmenorrhea in endometriosis is essentially palliative, since most of these treatment can only suppress disease progression and relieve its symptoms.

Objective: To compare the difference in dysmenorrhea scores pre and post treatment of dysmenorrhea in endometriosis patients who received laparoscopic ablation followed with GnRH agonist versus laparoscopic ablation therapy alone.

Method: This is an observational study with a retrospective cohort design. Endometriosis patients were identified through medical records at Dr Sardjito Hospital, Yogyakarta. Patients were categorized into laparoscopic ablation therapy followed by $\mathrm{GnRH}$ agonist group and laparoscopic ablation therapy only group. Evaluation of dysmenorrhoea scores were performed in 6 months after therapy.

Result and Discussion: A total of 88 subjects (44 subjects in each group) were eligible and gave their consent to participate. Patients who received laparoscopic ablation therapy followed by GnRH agonist showed greater VAS difference pre and post treatment $(6,27 \pm 0,22$ vs $4,20 \pm 1,17, p<0,001)$ compared with only ablation laparoscopic. This difference was not affected by age, BMI, and endometriosis stage. Eleven of the 44 subjects who received laparoscopic ablation followed by GnRH agonists developed side effects. There were 7 people with hot flushes, 3 people with decreased bone mineral density and 1 people with dry skin, whereas no subject in laparoscopic ablation group alone experienced them.

Conclusions: Laparoscopic ablation followed by GnRH agonist therapy was associated with greather difference in dysmenorrhea score pre and post treatment compared with laparoscopic ablation only. Laparoscopic ablation therapy followed with a GnRH agonist was associated with higher side effects.
\end{abstract}

Keywords: endometriosis, laparoscopic ablation, GnRH agonist, visual analog scale

\begin{abstract}
ABSTRAK
Latar Belakang: Dismenorea pada endometriosis adalah suatu kondisi yang memberikan dampak bermakna pada mutu kehidupan wanita. Penanganan dismenorea pada endometriosis saat ini pada hakikatnya masih belum berhasil menyembuhkannya, karena sebagian besar baru mampu menekan perkembangan penyakit dan menghilangkan gejalanya.

Tujuan: Membandingkan selisih skor dismenorea sebelum dan setelah terapi pada pasien endometriosis yang mendapatkan terapi ablasi laparoskopi dilanjutkan GnRH agonist versus ablasi laparoskopi saja.

Metode: Penelitian ini adalah penelitian observasional menggunakan rancangan penelitian kohort retrospektif. Pasien endometriosis diidentifikasi melalui rekam medis di RSUP DR Sardjito, Yogyakarta. Pasien dikelompokkan
\end{abstract}

\footnotetext{
1,2,3 Bagian Obstetri dan Ginekologi Fakultas Kedokteran Universitas Gadjah Mada
} 
menjadi kelompok terapi ablasi laparoskopi dilanjutkan dengan GnRH agonist dan terapi ablasi laparoskopi saja.Evaluasi untuk skor dismenorea dilakukan pada jangka waktu 6 bulan setelah terapi.

Hasil dan Pembahasan: Sebanyak 88 subyek (44 subyek dalam setiap kelompok) memenuhi kriteria penelitian dan memberikan persetujuan untuk diikutsertakan dalam penelitian. Pasien yang mendapatkan terapi ablasi laparoskopi dilanjutkan GnRH agonist menunjukkan selisih VAS sebelum dan setelah terapi yang secara signifikan lebih baik $(6,22 \pm 0,22$ vs $4,20 \pm 1,17 ; p<0,001)$ dibandingkan dengan ablasi laparoskopi saja. Perbedaan ini tidak dipengaruhi oleh umur, BMI, maupun derajat endometriosis. Sebelas dari 44 subyek yang mendapatkan ablasi laparoskopi dilanjutkan GnRH agonist mengalami efek samping, yaitu 7 orang mengalami hot flushes, 3 orang mengalami penurunan densitas masa tulang dan 1 orang mengalami kulit kering, sedangkan tidak ada subyek dalam kelompok ablasi laparoskopi saja yang mengalami efek samping.

Kesimpulan: Terapi ablasi laparoskopi yang dilanjutkan dengan $\mathrm{GnRH}$ agonist berhubungan dengan selisih skor dismenorea sebelum dan setelah terapi yang lebih tinggi dibandingkan dengan terapi ablasi laparoskopi saja. Terapi ablasi laparoskopi yang dilanjutkan dengan GnRH agonist berhubungan dengan tingkat efek samping yang lebih tinggi.

Kata kunci: endometriosis, ablasi laparoskopi, GnRH agonist, visual analog scale

\section{PENDAHULUAN}

Dismenorea merupakan kram menyakitkan di perut bagian bawah yang terjadi selama atau tepat sebelum menstruasi. Dismenorea dibagi menjadi dua sub-kategori. Dismenorea primer adalah nyeri haid tanpa kelainan organik yang dapat diidentifikasi dan umumnya terjadi pada wanita lebih muda dari 20 tahun. Dismenorea sekunder adalah nyeri menstruasi yang berhubungan dengan kondisi patologis yang bisa diidentifikasi, seperti endometriosis, penyempitan serviks atau adhesi pelvis, dan yang paling sering ditemukan pada wanita lebih dari 20 tahun. ${ }^{1}$

Nyeri panggul kronis yang terjadi lebih dari satu tahun dapat terjadi pada sekitar 15-20\% perempuan antara 18 dan 50 tahun. Survei di Eropa menunjukkan prevalensi dismenorea pada 12 penelitian yaitu $59 \%$ (Cl 95\% 49.1-71\%), Sindroma nyeri disebabkan oleh aktivasi nosiseptor dan transmisi sinyal dalam jalur rasa nyeri. Nyeri panggul kronis termasuk dismenorea primer dan sekunder. ${ }^{2}$

Penggunaan nonsteroidal obat anti-inflamasi atau acetaminophen dapat digunakan sebagai terapi, tetapi keefektifan obat ini belum ditunjang dengan penelitian yang memadai. Pil kontrasepsi oral, medroksiprogesteron asetat, dan levonorgestrel intrauterine relatif efektif untuk menghilangkan rasa sakit. Danazol dan berbagai GnRH ( gonadotropinreleasing hormone) analog juga telah terbukti efektif tetapi mungkin memiliki efek samping yang signifikan. Ablasi laparoskopi pada endometriosis dapat mengurangi nyeri dan meningkatkan tingkat kesuburan pada wanita dengan endometriosis. Presacral neurectomy sangat bermanfaat pada wanita dengan nyeri panggul kronis. Histerektomi dan bilateral salpingo-ooforektomi merupakan terapi definitif untuk mengatasi rasa nyeri akibat endometriosis dalam kurun waktu 10 tahun pada 90 persen pasien. $^{3}$

Penanganan gabungan pada pasien endometriosis, yaitu ablasi laparoskopi dilanjutkan dengan $\mathrm{GnRH}$ agonist berguna pada endometriosis aktif, campuran aktif dan nir-aktif, atau adanya lesi endometriosis yang sukar dikenali saat tindakan laparoskopi, dan ada keraguan tentang masih adanya lesi tersebut. Penanganan gabungan tersebut bertujuan untuk menghilangkan lesi yang tidak terablasi pada pembedahan dan mengurangi perlekatan. Secara umum, angka kekambuhan terutama untuk dismenorea mencapai $10 \%$ setelah pengobatan 1 tahun, sedangkan pada ablasi 
laparoskopi saja, angka kekambuhan sebesar $27 \%$ dengan waktu observasi yang sama. ${ }^{4}$

Tujuan dari penelitian ini adalah untuk mengetahui bahwa skor dismenorea sebelum dan setelah terapi pada pasien endometriosis yang mendapatkan terapi ablasi laparoskopi dilanjutkan $\mathrm{GnRH}$ agonist lebih baik dibandingkan ablasi laparoskopi saja.

\section{METODE}

Penelitian ini adalah penelitian observasional menggunakan rancangan penelitian kohort retrospektif. Sampel diambil dari pasien endometriosis dengan keluhan dismenorea yang diagnosisnya ditegakkan dengan laparoskopi di klinik permata hati dan poliklinik endokrinologi RSUP Dr. Sardjito Yogyakarta. Subyek dikelompokkan berdasarkan terapi ke dalam kelompok yang mendapat terapi ablasi laparoskopi+GnRH agonist dan kelompok yang mendapat terapi ablasi laparoskopi saja. Dalam penelitian ini skor dismenorea yang menurun sebesar 1,5 kali dianggap dapat menurunkan kejadian dismenorea, $\mathrm{SD}=2,73$ diambil dari penelitian oleh Hornstein dan kawan-kawan (1997), maka akan didapatkan besar sampel minimal untuk masingmasing kelompok sebanyak 44 partisipan.

Kriteria inklusi adalah pasien endometriosis dengan keluhan dismenorea yang diagnosisnya ditegakkan dengan laparoskopi, dan bersedia mengikuti penelitian dan telah menandatangani formulir kesediaan. Subyek dieksklusi dari penelitian jika mempunyai penyakit berat lain yang merupakan kontraindikasi atau tidak bersedia mengikuti program penelitian. Pemeriksaan evaluasi skor nyeri dan efek samping dilakukan pada titik waktu 6 bulan. Data diambil sejak bulan Januari 2013 sampai dengan Desember 2013.

1. Variabel bebas adalah terapi ablasi laparoskopi dilanjutkan GnRh agonist dan terapi ablasi laparoskopi saja. Variabel tergantung dalam penelitian ini adalah skor dismenorea dan efek samping. Efek samping dari ablasi laparoskopi adalah terjadinya, kram uterus, kram abdo- men, sistitis, endometritis, hematometra. Efek samping dari GnRH agonist adalah hipogonadism dan termasuk hot flushes, kekeringan vagina yang progresif, menurun-nya libido, depresi, iritabilitas, kelelahan, nyeri kepala, perubahan jaringan kulit dan penipisan mineral tulang. GnRH agonist yang digunakan dalam penelitian adalah leuprorelin acetate dengan dosis yang diberikan adalah 3,75 $\mathrm{mg} \mathrm{SC} / \mathrm{IM}$, diberikan pada 5 hari pertama dari siklus menstruasi, diulang tiap 4 minggu, diberikan selama 6 bulan. Derajat endometriosis ditegakkan dengan laparoskopi diagnostik, dikelompokkan menurut 4 kategori, yaitu: derajat I (minimal;1-5), derajad II (ringan: 615), derajad III (sedang: 16-40), derajad IV (berat: >40), skala pengukuran terlampir. Skor dismenorea didasarkan pada skor visual analog scale (VAS), diukur sebelum dan setelah terapi. ${ }^{10}$

2. Uji statistik diawali dengan analisis univariat untuk mengetahui karakteristik subyek penelitian dan melihat komparabilitas antar kelompok, dengan menghitung distribusi, frekuensi dan proporsi pada masing-masing kelompok. Analisis bivariat pada selisih VAS sebagai variabel tergantung menggunakan uji statistik independent t-test dan one-way ANOVA, sedangkan untuk data efek samping sebagai variabel tergantung menggunakan uji statistik chi square. Skor dismenorea dinyatakan dalam rerata \pm SD dan dianggap berbeda bermakna apabila $p<0.05$. analisis multivariat dilakukan dengan menggunakan ANCOVA dan regresi logistik.

\section{HASIL DAN PEMBAHASAN}

Pengambilan data dilakukan antara bulan Januari 2013 hingga Desember 2013. Sebanyak 88 subyek penelitian memenuhi kriteria inklusi dan memberikan persetujuan untuk diikutsertakan dalam penelitian. Masing-masing 44 subyek dimasukkan ke dalam kelompok terapi ablasi laparoskopi yang dilanjutkan dengan $\mathrm{GnRH}$ agonist dan kelompok terapi ablasi laparoskopi saja. 


\section{Analisis Univariat}

Rerata usia subyek penelitian adalah $32,61 \pm 5,90$ tahun, sebanyak 66 subyek (75\%) berusia antara 2034 tahun dan hanya 3 subyek $(3,4 \%)$ yang berusia di atas 45 tahun. Rerata BMI subyek penelitian adalah $22,73 \pm 3,26 \mathrm{~kg} / \mathrm{m}^{2}$, dimana sebanyak 66 subyek (75\%) memiliki berat badan normal, 7 subyek (8\%) underweight, dan 5 subyek (17\%) overweight atau gemuk. Sebelas subyek (12,5\%) mengalami efek samping. Sebanyak 9 subyek memiliki derajat endometriosis I, 14 subyek derajat endometriosis II, 18 subyek derajat endometriosis III, dan sebanyak 47 subyek memiliki endometriosis derajat IV.

Subyek penelitian secara keseluruhan menunjukkan perbaikan skor nyeri setelah terapi. Rerata skor VAS sebelum terapi adalah sebesar 7,58 $\pm 1,21$, angka ini menurun menjadi $2,36 \pm 1,83$ setelah terapi. Data lebih rinci mengenai karakteristik subyek penelitian ditampilkan pada tabel 1 dan tabel 2.

Tabel 1. Karakteristik subyek penelitian (variabel kategorikal)

\begin{tabular}{rlcc}
\hline \multicolumn{1}{c}{ Variabel } & $\mathrm{n}$ & Persentase (\%) \\
\hline Umur & & \\
a. $\quad 20-34 \mathrm{thn}$ & 66 & 75 \\
b. $\quad 35-44 \mathrm{thn}$ & 19 & 21,6 \\
c. $\quad 25 \mathrm{thn}$ & 3 & 3,4 \\
\hline BMI & & \\
a. $\quad<18,5 \mathrm{~kg} / \mathrm{m}^{2}$ & 7 & 8 \\
b. $\quad 18,5-24,9 \mathrm{~kg} / \mathrm{m}^{2}$ & 66 & 75 \\
c. $\quad 225 \mathrm{~kg} / \mathrm{m}^{2}$ & 5 & 17 \\
\hline Efek samping & & \\
a. Ada & 11 & 12,5 \\
b. Tidak ada & 77 & 87,5 \\
\hline Derajat endometriosis & & \\
a. Derajat I & 9 & 10,2 \\
b. Derajat II & 14 & 15,9 \\
c. Derajat III & 18 & 20,5 \\
d. Derajat IV & 47 & 53,4 \\
\hline
\end{tabular}

Tabel 2. Karakteristik subyek penelitian (variabel kontinyu)

\begin{tabular}{lr}
\hline Variabel & \multicolumn{1}{c}{ Rerata \pm SD } \\
\hline Umur & $32,61 \pm 5,90$ \\
BMI & $22,73 \pm 3,26$ \\
VAS pre-terapi & $7,58 \pm 1,21$ \\
VAS post-terapi & $2,36 \pm 1,83$ \\
\hline
\end{tabular}

\section{Analisis Bivariat}

\section{a. Nilai VAS}

Analisis paired t test dilakukan untuk mengetahui perbedaan skor VAS antara sebelum dan setelah terapi pada kedua kelompok terapi. Kelompok terapi ablasi laparoskopi yang dilanjutkan $\mathrm{GnRH}$ agonist menunjukkan perbedaan skor VAS sebelum dan setelah terapi yang bermakna dengan perbedaan rerata sebesar 6,22. Kelompok ablasi laparoskopi saja juga menunjukkan perbedaan skor VAS sebelum dan setelah terapi yang bermakna dengan perbedaan rerata 4,20. 


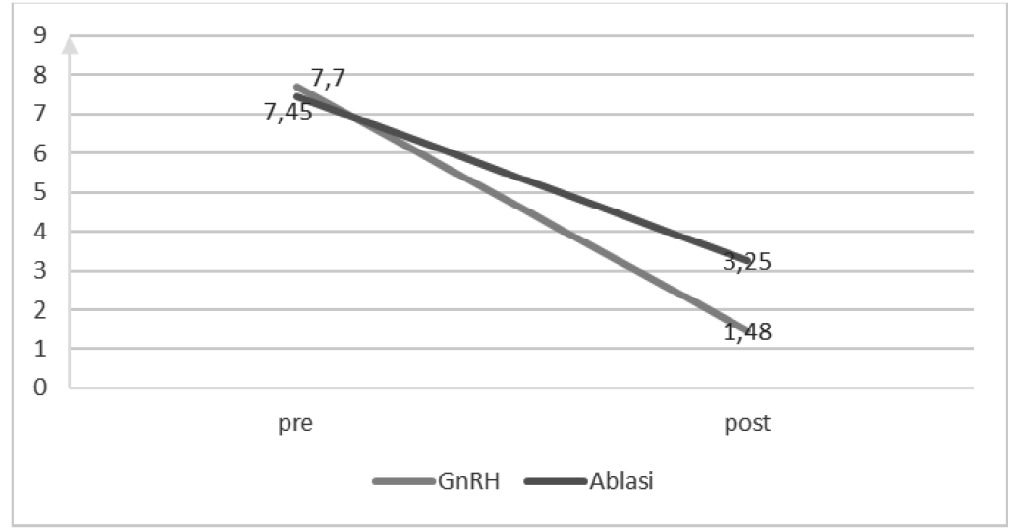

Gambar 2. Grafik perubahan rerata skor VAS sebelum dan setelah terapi

Tabel 3. Analisis paired t-test antara variabel bebas (ablasi laparoskopi+GnRH agonist, ablasi laparoskopi saja) dengan variabel tergantung( nilai VAS)

\begin{tabular}{|c|c|c|c|c|c|c|}
\hline \multirow{2}{*}{ Variabel } & \multicolumn{2}{|c|}{ Skor VAS (rerata $\pm S D$ ) } & \multirow{2}{*}{ Selisih rerata } & \multirow{2}{*}{$\mathrm{T}$} & \multirow{2}{*}{$\mathrm{Cl} 95 \%$} & \multirow{2}{*}{$P$} \\
\hline & pre -terapi & post -terapi & & & & \\
\hline $\begin{array}{l}\text { Ablasi + GnRH } \\
\text { agonist }\end{array}$ & $7,70 \pm 1,09$ & $1,48 \pm 1,73$ & $6,22 \pm 0,22$ & 27,37 & $5,77-6,67$ & $<0,001$ \\
\hline Ablasi & $7,45 \pm 1,32$ & $3,25 \pm 1,46$ & $4,20 \pm 1, \quad 17$ & 23,66 & $3,84-4,56$ & $<0,001$ \\
\hline
\end{tabular}

Analisis kemudian dilanjutkan dengan uji independent $t$ test untuk menilai seberapa besar perbedaan rerata perubahan skor VAS antara kelompok ablasi laparoskopi yang dilanjutkan GnRH agonist dan kelompok ablasi laparoskopi saja. Hasil analisis menunjukkan bahwa kelompok ablasi laparoskopi yang dilanjutkan GnRH agonist memiliki perubahan skor VAS yang secara bermakna lebih kuat jika dibandingkan kelompok ablasi laparoskopi saja, dengan perbedaan rerata sebesar 2,02.

Tabel 4. Analisis independent t-test antara variabel bebas (ablasi laparoskopi+GnRH agonist, ablasi laparoskopi saja) dengan variabel tergantung (selisih VAS)

\begin{tabular}{lccccc}
\hline \multicolumn{1}{c}{ Variabel } & VAS (rerata \pm SD) & Selisih rerata & T & Cl 95\% & P \\
\hline $\begin{array}{l}\text { Ablasi + GnRH } \\
\text { agonist }\end{array}$ & $6,23 \pm 1,48$ & 2,02 & 7,11 & $1,45-2,58$ & $<0,001$ \\
Ablasi & $4,20 \pm 1,17$ & & & & \\
\hline
\end{tabular}

Uji chi square dilakukan untuk menilai perbedaan proporsi umur, BMI dan derajat endometriosis antar kelompok terapi. Hasil analisis menunjukkan bahwa kelompok ablasi laparoskopi yang dilanjutkan $\mathrm{GnRH}$ agonist memiliki perbandingan proporsi subyek dengan derajat endometriosis IV terhadap subyek dengan derajat endometriosis I yang secara bermakna lebih rendah jika dibandingkan kelompok ablasi laparoskopi saja, dengan RR sebesar 2,87. Umur dan BMI tidak memiliki perbedaan proporsi yang bermakna antar kelompok terapi. 
Tabel 5. Analisis chi square antara variabel bebas (ablasi laparoskopi+GnRH agonist, ablasi laparoskopi saja) dengan variabel luar (umur)

\begin{tabular}{cccccccc}
\hline & \multicolumn{2}{c}{ Ablasi } & \multicolumn{2}{c}{ Ablasi + GnRH } \\
Variabel & \multicolumn{2}{c}{ agonist } & RR & Cl 95\% & P \\
\cline { 2 - 5 } & $\mathrm{n}$ & $\%$ & $\mathrm{n}$ & $\%$ & & & \\
\hline Umur & & & & & & & \\
$20-34$ thn & 31 & 51,67 & 29 & 48,33 & 1,11 & $0,69-1,77$ & 0,64 \\
$\geq 35$ thn & 13 & 46,43 & 15 & 53,57 & & & \\
\hline
\end{tabular}

Tabel 6. Analisis chi square antara variabel bebas (ablasi laparoskopi+GnRH agonist, ablasi laparoskopi saja) dengan variabel luar (BMI)

\begin{tabular}{|c|c|c|c|c|c|c|c|}
\hline \multirow[t]{2}{*}{ Variabel } & \multicolumn{2}{|c|}{ Ablasi } & \multicolumn{2}{|c|}{$\begin{array}{c}\text { Ablasi + GnRH } \\
\text { agonist }\end{array}$} & \multirow[t]{2}{*}{$\mathrm{RR}$} & \multirow[t]{2}{*}{ CI 95\% } & \multirow[t]{2}{*}{$P$} \\
\hline & $\mathbf{n}$ & $\%$ & $\mathrm{n}$ & $\%$ & & & \\
\hline \multicolumn{8}{|l|}{ BMI } \\
\hline$<18,5 \mathrm{~kg} / \mathrm{m}^{2}$ & 3 & 42,86 & 4 & 57,14 & 0,72 & $0,28-1,87$ & 0,65 \\
\hline $18,5-24,9 \mathrm{~kg} / \mathrm{m}^{2}$ & 31 & 48,44 & 33 & 51,56 & 0,88 & $0,36-2,15$ & 1,00 \\
\hline$\geq 25 \mathrm{~kg} / \mathrm{m}^{2}$ & 10 & 58,82 & 7 & 41,18 & & & \\
\hline
\end{tabular}

Tabel 7. Analisis chi square antara variabel bebas (ablasi laparoskopi+GnRH agonist, ablasi laparoskopi saja) dengan variabel luar (derajat endometriosis)

\begin{tabular}{|c|c|c|c|c|c|c|c|}
\hline \multirow[t]{2}{*}{ Variabel } & \multicolumn{2}{|c|}{ Ablasi } & \multicolumn{2}{|c|}{$\begin{array}{c}\text { Ablasi + GnRH } \\
\text { agonist }\end{array}$} & \multirow[t]{2}{*}{$\mathrm{RR}$} & \multirow[t]{2}{*}{ CI 95\% } & \multirow[t]{2}{*}{$\mathbf{P}$} \\
\hline & $\mathrm{n}$ & $\%$ & $\mathrm{n}$ & $\%$ & & & \\
\hline \multicolumn{8}{|c|}{ Derajat endometriosis } \\
\hline Derajat IV & 30 & 63,83 & 17 & 36,17 & 2,87 & $0,83-9,93$ & 0,02 \\
\hline Derajat IIII & 8 & 44,44 & 10 & 55,56 & 2,00 & $0,53-7,53$ & 0,40 \\
\hline Derajat II & 4 & 28,57 & 10 & 71,43 & 1,28 & $0,29-5,62$ & 1,00 \\
\hline Derajat I & 2 & 22,22 & 7 & 77,78 & & & \\
\hline
\end{tabular}

Analisis bivariat pada penelitian ini juga dilakukan untuk melihat hubungan antara variabel luar dengan selisih skor VAS sebelum dan setelah terapi. Hasil analisis menunjukkan bahwa umur, BMI maupun derajat endometriosis tidak memiliki hubungan yang bermakna dengan selisih VAS sebelum dan setelah terapi.

Tabel 8. Analisis independent $t$ test antara variabel luar (umur) dengan variabel tergantung (selisih VAS)

\begin{tabular}{|c|c|c|c|c|c|}
\hline Variabel & (rerata $\mathrm{a}$ SD) & Selisih rerata & $\mathrm{T}$ & $\mathrm{Cl} 95 \%$ & $P$ \\
\hline \multicolumn{6}{|l|}{ Umur } \\
\hline $20-34$ thn & $5,31 \pm 1,76$ & $0,31 \pm 0,38$ & 0,82 & $-0,44-1,07$ & 0,20 \\
\hline$\geq 35$ thn & $5,00 \pm 0,27$ & & & & \\
\hline
\end{tabular}


Tabel 9. Analisis one way ANOVA antara variabel variabel luar (BMI) dengan variabel tergantung (selisih VAS)

\begin{tabular}{llll}
\hline \multicolumn{1}{c}{ Variabel } & Rerata \pm SD & $F$ & $p$ \\
\hline BMI & & & \\
$<18,5 \mathrm{~kg} / \mathrm{m}^{2}$ & $4,57 \pm 1,90$ & 0,64 & 0,86 \\
$18,5-24,9 \mathrm{~kg} / \mathrm{m}^{2}$ & $5,23 \pm 1,67$ & & \\
$\geq 25 \mathrm{~kg} / \mathrm{m}^{2}$ & $5,41 \pm 1,58$ & & \\
\hline
\end{tabular}

Tabel 10. Analisis one way ANOVA antara variabel luar (derajat endometriosis) dengan variabel tergantung (selisih VAS)

\begin{tabular}{llcc}
\hline \multicolumn{1}{c}{ Variabel } & Rerata \pm SD & $F$ & $p$ \\
\hline Derajat endometriosis & & & \\
Deraja t IV & $5,53 \pm 1,85$ & 1,55 & 0,12 \\
Derajat IIII & $5,05 \pm 1,11$ & & \\
Derajat II & $4,50 \pm 1,45$ & & \\
Derajat I & $5,00 \pm 1,73$ & & \\
\hline
\end{tabular}

\section{b. Efek Samping}

Analisis bivariat menggunakan uji chi square dilakukan untuk mengetahui pengaruh terapi terhadap kemunculan efek samping. Hasil penelitian menunjukkan bahwa terdapat 11 subyek yang mendapatkan terapi ablasi laparoskopi dilanjutkan dengan $\mathrm{GnRH}$ agonist yang mengalami efek samping, tetapi tidak ada satupun subyek yang mendapatkan terapi ablasi laparoskopi saja yang mengalami efek samping. Terapi ablasi laparoskopi yang dilanjutkan dengan $\mathrm{GnRH}$ agonist berhubungan dengan risiko yang lebih tinggi untuk kemunculan efek samping dengan OR sebesar 3,20.

Tabel 11. Uji chi square antara variabel bebas (terapi) dan variabel tergantung (efek samping)

\begin{tabular}{|c|c|c|c|c|c|c|c|}
\hline \multirow{2}{*}{ Variabel } & \multicolumn{2}{|c|}{ Ada } & \multicolumn{2}{|c|}{ Tidak ada } & \multirow{2}{*}{$\mathrm{RR}$} & \multirow{2}{*}{ CI 95\% } & \multirow{2}{*}{$P$} \\
\hline & $\mathbf{n}$ & $\%$ & $\mathrm{~N}$ & $\%$ & & & \\
\hline Ablasi + GnRH agonist & 11 & 25 & 33 & 75 & 3,20 & $1,26-8,11$ & 0,01 \\
\hline Ablasi laparoskopi & 0 & 0 & 44 & 100 & & & \\
\hline
\end{tabular}

Note: digunakan Yate's Correction 0,5

Analisis bivariat untuk menilai hubungan antara variabel luar, yaitu umur, BMI dan derajat endometriosis dengan efek samping dilakukan menggunakan uji chi square. Hasil dari analisis menunjukkan bahwa kemunculan efek samping memiliki hubungan yang bermakna dengan BMI, tetapi tidak dengan umur dan derajat endometriosis. 
Tabel 12. Analisis chi square antara variabel luar (umur) dengan variabel tergantung (efek samping)

\begin{tabular}{|c|c|c|c|c|c|c|c|}
\hline \multirow{2}{*}{ Variabel } & \multicolumn{2}{|c|}{ ada } & \multicolumn{2}{|c|}{ Tidak ada } & \multirow{2}{*}{ RR } & \multirow{2}{*}{ Cl 95\% } & \multirow{2}{*}{$P$} \\
\hline & $\mathrm{n}$ & $\%$ & $\mathrm{n}$ & $\%$ & & & \\
\hline \multicolumn{8}{|l|}{ Umur } \\
\hline $20-34$ thn & 6 & 10 & 54 & 90 & 1,35 & $0,68-1,22$ & 0,72 \\
\hline$\geq 35$ thn & 5 & 17,86 & 23 & 82,14 & & & \\
\hline
\end{tabular}

Tabel 13. Analisis chi square antara variabel luar (BMI) dengan variabel tergantung (efek samping)

\begin{tabular}{|c|c|c|c|c|c|c|c|}
\hline \multirow{2}{*}{ Variabel } & \multicolumn{2}{|c|}{ Ada } & \multicolumn{2}{|c|}{ Tidak ada } & \multirow{2}{*}{ RR } & \multirow{2}{*}{$\mathrm{Cl} 95 \%$} & \multirow{2}{*}{$P$} \\
\hline & $\mathrm{n}$ & $\%$ & $\mathrm{n}$ & $\%$ & & & \\
\hline \multicolumn{8}{|l|}{ BMI } \\
\hline$<18,5 \mathrm{~kg} / \mathrm{m}^{2}$ & 3 & 42,86 & 4 & 57,14 & 2,76 & $1,27-4,94$ & 0,03 \\
\hline $18,5-24,9 \mathrm{~kg} / \mathrm{m}^{2}$ & 6 & 9,38 & 58 & 90,62 & 0,91 & $0,88-2,14$ & 0,94 \\
\hline$\geq 25 \mathrm{~kg} / \mathrm{m}^{2}$ & 2 & 11,77 & 15 & 88,24 & & & \\
\hline
\end{tabular}

Tabel 14. Analisis chi square antara variabel luar (derajat endometriosis) dengan variabel tergantung (efek samping)

\begin{tabular}{|c|c|c|c|c|c|c|c|}
\hline \multirow{2}{*}{ Variabel } & \multicolumn{2}{|c|}{ Ada } & \multicolumn{2}{|c|}{ Tidak ada } & \multirow{2}{*}{$\mathrm{RR}$} & \multirow{2}{*}{$\mathrm{Cl} 95 \%$} & \multirow{2}{*}{$p$} \\
\hline & $\mathrm{n}$ & $\%$ & $\mathbf{n}$ & $\%$ & & & \\
\hline \multicolumn{8}{|c|}{ Derajat endometriosis } \\
\hline Derajat IV & 7 & 14,89 & 40 & 85,10 & \multirow{4}{*}{$\begin{array}{c}1,75 \\
1 \\
0,87\end{array}$} & \multirow{2}{*}{$0,99-4,35$} & \multirow{2}{*}{0,09} \\
\hline Derajat III & 2 & 11,11 & 16 & 88,89 & & & \\
\hline Derajat II & 1 & 7,14 & 13 & 92,86 & & 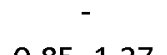 & 1 \\
\hline Derajat I & 1 & 11,11 & 8 & 88,89 & & $0,85-1,27$ & 0,07 \\
\hline
\end{tabular}

\section{Analisis multivariat}

\section{a. Selisih VAS}

Analisis multivariat untuk selisih VAS sebagai variabel tergantung menggunakan uji ANCOVA. Hasil analisis menunjukkan bahwa terapi memiliki pengaruh yang signifikan dan independent terhadap selisih VAS. Umur, BMI dan derajat endometriosis tidak mempengaruhi hubungan antara terapi dan selisih VAS. Hasil analisis ANCOVA ditunjukkan secara rinci dalam tabel 15.

Tabel 15. Analisis ANCOVA antara variabel bebas (terapi), variabel luar (BMI, derajat endometriosis) dengan variabel tergantung (selisih VAS)

\begin{tabular}{lccccc}
\hline \multicolumn{1}{c}{ Variabel } & $\begin{array}{c}\text { Type III sum of } \\
\text { squares }\end{array}$ & df & Mean square & F & P \\
\hline BMI & 1,09 & 1 & 1,09 & 0,60 & 0,43 \\
Derajat endometriosis & 0,03 & 1 & 0,03 & 0,02 & 0,88 \\
Terapi & 79,67 & 1 & 79,67 & 44,09 & $<0,001$ \\
\hline
\end{tabular}




\section{b. Efek samping}

Analisis multivariat untuk efek samping sebagai variabel tergantung menggunakan uji regresi logistik. Uji regresi logistik tidak dapat menganalisis hubungan antara terapi dan efek samping. BMI dan derajat endometriosis tidak memiliki hubungan yang signifikan dan independent dengan efek samping. Hasil analisis uji regresi logistik ditunjukkan secara rinci dalam tabel 16.

Tabel 16. Analisis regresi logistik antara variabel bebas (terapi) dan variabel tergantung (efek samping) yang dikendalikan oleh variabel luar ( BMI, umur, dan derajat endometriosis)

\begin{tabular}{lccc}
\hline & Model 1 & Model 2 & Model 3 \\
Variabel & OR & OR & OR \\
& Cl 95\% & Cl 95\% & Cl 95\% \\
& p & p & $\mathrm{P}$ \\
\hline Umur & 0,87 & 0,85 & 0,86 \\
& $0,77-0,99$ & $0,73-0,98$ & $0,74-1,01$ \\
Derajat & 0,04 & 0,03 & 0,07 \\
endometriosis & & 6,92 & 6,22 \\
& & $0,79-59,97$ & $0,73-53,05$ \\
BMI & & 0,07 & 0,09 \\
& & & 0,92 \\
& & & $0,74-1,15$ \\
\end{tabular}

Hasil analisis penelitian menemukan bahwa kedua terapi berhubungan dengan perbaikan skor nyeri pada pasien endometriosis. Terapi ablasi laparoskopi yang dilanjutkan dengan $\mathrm{GnRH}$ agonist berhubungan dengan perbaikan nyeri yang lebih baik dan signifikan jika dibandingkan dengan terapi ablasi laparoskopi saja. Hubungan ini tidak dipengaruhi oleh variabel luar.

Beberapa penelitian yang dilakukan sebelumnya menunjukkan bahwa pemberian GnRH agonist pasca operasi tidak berhubungan dengan perbaikan nyeri haid yang lebih baik jika dibandingkan dengan hanya laparoskopi saja, tetapi GnRH agonist pasca operasi mungkin berhubungan dengan waktu yang lebih lama untuk terjadinya kekambuhan nyeri haid. ${ }^{5}$ Penelitian yang dilakukan oleh Song \& Zhang ${ }^{6}$ melaporkan bahwa kombinasi terapi ablasi laparoskopi dan $\mathrm{GnRH}$ agonist lebih efektif dalam terapi endometriosis, menunjukkan tingkat kekambuhan yang lebih rendah dan tingkat kehamilan lebih tinggi jika dibandingkan dengan kelompok yang mendapatkan terapi ablasi laparoskopi saja.
Hornstein et al. ${ }^{7}$ meneliti tentang keefektifan GnRH agonist naferelin dibandingkan dengan plasebo setelah terapi ablasi laparoskopi. Hasil penelitian menemukan bahwa meskipun skor dari nyeri haid menunjukkan penurunan yang signifikan dalam kelompok nafarelin dan plasebo setelah terapi selama 6 bulan, hasil dari pemeriksaan secara umum menunjukkan perbaikan yang signifikan dalam kelompok nafarelin dan tidak ada perbaikan signifikan dalam kelompok yang mendapatkan plasebo setelah ablasi laparoskopi pada 6 bulan terapi. Pemberian nafarelin setelah ablasi laparoskopi memperlambat secara signifikan kekambuhan gejala endometriosis yang memerlukan terapi lebih lanjut.

$\mathrm{GnRH}$ agonist mampu menurunkan fungsi pituitari, meningkatkan pelepasan awal yang kemudian diikuti dengan penurunan gonadotropin FSH dan LH. Mekanisme kerja GnRH agonist dalam endometriosis diduga dengan menciptakan sebuah keadaan defisiensi estrogen hingga sekitar 2 minggu setelah dimulainya terapi. GnRH agonist juga diketahui memiliki efek langsung pada steroidogene- 
sis ovarium, tidak tergantung pada efek pituitari dan memiliki efek langsung pada pertumbuhan implan endometrial. Sel yang terpapar GnRH agonist mengalami peningkatan apoptosis dengan penurunan pelepasan sitokin promitogenik seperti IL$1 \beta$ (Interleukin-1 $\beta$ ) dan VEGF (Vascular Endotelial Growth Factor), keduanya diduga berhubungan dengan pertumbuhan endometriosis. ${ }^{8}$

Sebanyak sebelas subyek mengalami efek samping dan semuanya berada dalam kelompok ablasi laparoskopi yang dilanjutkan dengan $\mathrm{GnRH}$ agonist. Analisis bivariat juga menemukan hubungan yang signifikan antara BMI dan efek samping. Efek samping tersebut adalah tujuh orang mengalami hot flushes, tiga orang mengalami penurunan densitas massa tulang dan satu orang mengalami kulit kering. Semua efek samping yang terjadi tersebut merupakan efek samping dari GnRH agonist. Analisis multivariat tidak dapat menganalisis pengaruh terapi terhadap efek samping, tetapi analisis multivariat ini menemukan bahwa efek samping memiliki hubungan yang signifikan dan independent dengan umur pasien.

Penelitian kali ini menemukan tingkat efek samping untuk ablasi laparoskopi dilanjutkan dengan GnRH agonist yang lebih tinggi daripada penelitian sebelumnya, yaitu sebesar $25 \%$. Penelitian sebelumnya menemukan tingkat efek samping sebesar $21 \%$ pada kelompok pasien yang mendapatkan kombinasi ablasi laparoskopi dan GnRH agonist, termasuk perdarahan vaginal ireguler yang terkait dengan kadar estrogen yang rendah. ${ }^{6}$ Efek samping karena terapi GnRH agonist antara lain efek samping karena hipogonadisme sekunder (hot flushes, berkeringat, kekeringan vagina, dsb). Terapi GnRH agonist juga dapat memicu penurunan yang dramatis dalam Bone Mineral Density (BMD). ${ }^{9}$

Pemberian terapi "add-back" dengan progesteron atau kombinasi estrogen dan progesteron diduga mampu menurunkan tingkat keparahan efek samping hipoestrogenik yang menyertai terapi $\mathrm{GnRH}$ agonist. Teori yang mendasari terapi add-back adalah "hipotesis ambang batas estrogen", yang menyata- kan bahwa jumlah estrogen dan/atau progesteron yang diperlukan untuk mencegah hot flushes, bone loss dan gejala dan efek samping hipoestrogenik lainnya lebih rendah daripada yang diperlukan untuk memicu terjadinya endometriosis. ${ }^{10}$

\section{Kelemahan Penelitian}

Rancangan penelitian yang retrospektif tidak memungkinkan penilaian nyeri secara serial. Penelitian prospektif dengan pemeriksaan subyek secara serial akan memungkinkan penentuan titik waktu kapan subyek mulai merasakan penurunan nyeri dan kapan penurunan nyeri mencapai maksimal.

\section{KESIMPULAN DAN SARAN}

Dari penelitian ini bisa disimpulkan bahwa terapi ablasi laparoskopi yang dilanjutkan dengan $\mathrm{GnRH}$ agonist berhubungan dengan perbaikan skor dismenorea sebelum dan setelah terapi yang lebih signifikan dibandingkan dengan terapi ablasi laparoskopi saja. Perbedaan ini tidak dipengaruhi oleh umur, BMI maupun derajat endometriosis.

Terapi ablasi laparoskopi yang dilanjutkan dengan $\mathrm{GnRH}$ agonist berhubungan dengan tingkat efek samping yang lebih tinggi dibandingkan dengan terapi ablasi laparoskopi saja. Umur berpengaruh terhadap kemunculan efek samping yang disebabkan karena terapi.

Terapi ablasi laparoskopi yang dilanjutkan dengan $\mathrm{GnRH}$ agonist perlu dipertimbangkan untuk dapat diberikan pada pasien endometriosis dengan keluhan dismenorea. Klinisi perlu mengawasi kemunculan efek samping pada pasien endometriosis yang mendapatkan terapi ablasi laparoskopi yang dilanjutkan dengan $\mathrm{GnRH}$ agonist.

Diperlukan penelitian dengan rancangan kohort prospektif untuk mendapatkan kesimpulan yang lebih jelas tentang keamanan terapi serta mengetahui titik waktu awal penurunan nyeri dan waktu terjadinya penurunan nyeri maksimal. 


\section{DAFTAR PUSTAKA}

1. Montgomery, Endometriosis A Guide for Patients, American Society Reproductive Medicine; (205) 978-5000 (2012).

2. Sa'adi, A, The Role of Laparoscopic Uterine Nerve Ablation (LUNA) and Presacral Neurectomy (PSN) of Pelvic Pain Management, World Journal of Laparoscopic Surgery ;1(3):39-45 (2008).

3. Mounsey, A.L., Wilgus, A. \& Slawson, D.C. Diagnosis and Management of Endometriosis, Am Fam Physician;74:594-600, 601-2 (2006).

4. Jacoeb T.Z., Hadisaputra W. (2009) Penanganan Endometriosis, Panduan Klinis dan Algoritme, cetakan ke1, Sagung Seto.

5. Yeung Jr, P. P., Shwayder, J., \& Pasic, R. P, Laparoscopic management of endometriosis: comprehensive review of best evidence. Journal of minimally invasive gynecology, 16(3), 269-281 (2009).

6. Song, J. H., Lu, H., Zhang, J., \& Li, B., [Clinical study on the efectiveness and safety of combined laparoscopy and gonadotropin-releasing hormone agonist in the treatment of endometriosis]. Zhonghua fu chan ke za zhi, 48(8), 584-5888 (abstract) (2013)..

7. Mark, D., Hornstein, M.D., Robert Hemmings, M.D., A. Albert Yuzpe, M.D.W. \& LeRoy Heinrichs, M. D, Use of nafarelin versus placebo after reductive laparoscopic surgery for endometriosis, Fertility And Sterility, vol 68, No. 5 (1997).

8. Batzer, F. R., GnRH analogs: option for endometriosis-associated pain treatment. Journal of minimally invasive gynecology, 13(6), 539-545(2006).

9. Fernandez, H., Lucas, C., Hedon, B., Meyer, J. L., Mayenga, J. M., \& Roux, C, One year comparison between two add-back therapies in patients treated with a GnRH agonist for symptomatic endometriosis: a randomized double-blind trial. Human Reproduction, 19(6), 1465-1471(2004).

10. Practice Committee of American Society for Reproductive medicine. (2008). Treatment of pelvic pain associated with endometriosis. Fertility and sterility, 90(5 Suppl), S260. 